\title{
PERAN KOMITMEN PADA HUBUNGAN ANTARA TANGGUNG JAWAB SOSIAL PERUSAHAAN PERSEPSIAN DAN PEMBERDAYAAN KARYAWAN
}

\author{
Ayu Vilda Wati ${ }^{1}$ \\ Fakultas Ekonomi, Universitas Setia Budi \\ (ayufilda4589@gmail.com) \\ Nang Among Budiadi ${ }^{2}$ \\ Fakultas Ekonomi, Universitas Setia Budi \\ (nangamongbudiadi@gmail.com) \\ Sugiyarmasto ${ }^{3}$ \\ Fakultas Ekonomi, Universitas Setia Budi \\ (syarmasto@yahoo.com) \\ Ariefah Yulandari ${ }^{4}$ \\ Fakultas Ekonomi, Universitas Setia Budi \\ (yolanyolan79.feusb@gmail.com)
}

\begin{abstract}
ABSTRAK
Penelitian ini bertujuan untuk menguji komitmen pada Tanggung Jawab Sosial Perusahaan persepsian dan pemberdayaan karyawan. Komitmen karyawan yang baik maka karyawan akan merasa sepaham, cocok dengan organisasi dan karyawan tersebut semakin loyal sehubungan dengan itu akan bersifat positif dan karyawan bersedia untuk selalu komit sehingga siap diberdayakan. Data yang diperoleh melalui kuesioner yang dibagikan kepada karyawan di RSJD dr. Arif Zainudin Surakarta. Teknik penyampelan yang digunakan adalah cluster sampling dengan populasi karyawan medis maupun non medis sebanyak 80 responden. Uji hipotesis dilakukan dengan menggunakan analisis regresi bertingkat.
\end{abstract}

Kata kunci: Tanggung Jawab Sosial Perusahaan persepsian, pemberdayaan karyawan, komitmen.

\section{A. PENDAHULUAN}

Karyawan sebagai aset penting organisasi perlu diajak untuk ikut serta memikirkan dan menangani permasalahan strategis bahkan sampai diberikannya tanggung jawab dalam rangka mencapai tujuan organisasi (Kusdiarti, (1999). Bowen and Lawyer, (1992) pemberdayaan "sebagai informasi tentang kinerja organisasi, informasi penghargaan berdasarkan kinerja organisasi, pengetahuan yang memungkinkan karyawan untuk memahami dan berkontribusi terhadap kinerja organisasi, dan memberikan kekuatan kepada karyawan untuk membuat keputusan yang mempengaruhi kinerja dan arah organisasi.

Pengelola perusahaan harus memberdayakan karyawannya, kalau ingin karyawannya memiliki komitmen serta etos kerja yang baik, sehingga kinerja karyawan meningkat. Pemberdayaan dapat dilakukan melalui pemberian tanggung jawab serta wewenang yang lebih, yang akan 
menciptakan keinginan untuk bekerja dan memberikan yang terbaik untuk pekerjaannya (Arifin, 2014). Dizgah et al (2011) menyatakan bahwa pemberdayaan dapat mempengaruhi peningkatan pembangunan dan efektivitas organisasi. Pemberdayaan karyawan bisa dikatakan sebagai partisipasi manajemen yang melibatkan karyawan untuk bertanggung jawab di dalam proses kerjanya, (Elnaga dan Amen, 2014).

Komitmen mempunyai peran dalam meningkatkan pemberdayaan karyawan terhadap tanggung jawab sosial. Peran yang dikembangkan adalah membangun hubungan untuk menciptakan kepercayaan antar personal. Collier dan Esteban (2007) melihat ketergantungan organisasi pada respon karyawan terhadap tanggung jawab sosial perusahaan untuk menjalankan tanggung jawab sosial yang efektif. Rodrigo dan Arenas (2008) terciptanya komitmen termotivasi oleh pribadi karyawan itu sendiri, dengan melakukan kegiatan tanggung jawab sosial perusahaan. Sikap tidak peduli karyawan dipandang sebagai upaya yang tidak berorientasi pada tujuan. Oleh karena itu karyawan harus memahami program tanggung jawab sosial dan peranan organisasi. Hal tersebut timbul dari nilai-nilai pegawai. Pegawai bertahan menjadi anggota organisasi karena ada kesadaran bahwa berkomitmen terhadap organisasi merupakan hal yang memang seharusnya dilakukan jadi karena mereka merasa berkewajiban. Komitmen perusahaan terhadap tanggung jawab sosial sangat tinggi karena dapat meningkatkan perilaku tentang tanggung jawab sosial perusahaan. Mutiara (2004) komitmen organisasi sebagai kecenderungan karyawan untuk terikat dalam kegiatan yang konsisten. Sehingga tanggung jawab sosial perusahaan dapat mempengaruhi adanya komitmen organisasi dan pemberdayaan karyawan. Penelitian ini membahas mengenai pengaruh tanggung jawab sosial perusahaan terhadap komitmen organisasi dan pemberdayaan karyawan.

\section{B. LANDASAN TEORI}

\section{Pemberdayaan Karyawan Dalam Kegiatan CSR}

Menurut Appelbaum dan Hare (1996) pemberdayaan adalah hasil proses menimbang, mengintegrasikan dan mengevaluasi informasi tetang kemampuan diri sendiri yang akan mempengaruhi pilihan dan upaya yang dilakukan untuk menyelesaikan suatu pekerjaan.Dewettinck, et al.,(2011), menyatakan organisasi harus memberdayakan karyawan mereka untuk membuat mereka bertekad, setia dan senang sehingga pada gilirannya mereka akan menggunakan keterampilan dan kemampuan mereka untuk mencapai secara keseluruhan tujuan sebuah organisasi.

Berdasarkan pada penjelasan diatas, maka dapat disimpulkan bahwa pemberdayaan karyawan sebagai upaya yang dilakukan seorang pimpinan kepada karyawan dalam menjalankan proses dan mengevaluasi hasil dari tugas-tugas yang sudah dilaksanakan. 


\section{Tanggung Jawab Sosial Perusahaan Persepsian}

Pada tahun 1970, perkembangan definisi tanggung jawab sosial perusahaan semakin pesat, dimana ada kewajiban bagi setiap perusahaan untuk melaksanakan kegiatan di bidang tanggung jawab sosial perusahaan. Ide dasar tanggung jawab sosial perusahaan adalah dari keputusan perusahaan yang mempengaruhi stakeholder secara sosial dan perusahaan harus bertanggung jawab terhadap keputusan yang diambilnya Caecelia, (2008).Amiruddin (2009) menyatakan bahwa tanggung jawab sosial perusahaan sama dengan kedudukan sosial yang mereka miliki, sehingga dalam jangka panjang pengusaha yang tidak menggunakan kekuasaan dengan bertanggung jawab sesuai dengan anggapan masyarakat akan kehilangan kekuasaan yang mereka miliki saat ini.Atas dasar penjelasan tersebut, maka dapat diajukan hipotesis:

$\mathrm{H} 1$ : Tanggung jawab sosial perusahaan persepsian berpengaruh positif terhadap pemberdayaan karyawan dalam kegiatan tanggung jawab sosial perusahaan.

H2 : Tanggung jawab sosial perusahaan persepsian berpengaruh positif terhadap komitmen.

\section{Komitmen Terhadap Kegiatan Tanggung Jawab Sosial Perusahaan}

Mutiara (2004) menyatakan komitmen organisasi adalah menggambarkan sebagai kecenderungan untuk terikat dalam kegiatan yang konsisten. Sedangkan menurut Robbins (2006) komitmen organisasi adalah sejauh mana seseorang karyawan memihak pada suatu organisasi tertentu dan tujuantujuannya, dan berniat memelihara keanggotaan dalam organisasi itu. Komitmen tinggi dalam organisasi, berarti terdapat keberpihakan pada organisasi yang tinggi pula. Komitmen sebagai prediktor kinerja yang lebih baik dan bersifat global, dan bertahan dalam organisasi sebagai suatu keseluruhan daripada kepuasan kerja semata. Seseorang dapat tidak puas dengan organisasi. Ketidakpuasan tersebut dapat menjalar ke seluruh organisasi, sehingga mendorong seseorang untuk mempertimbangkan diri minta berhenti.

Atas dasar penjelasan tersebut, maka dapat diajukan hipotesis :

H3 : Komitmen berpengaruh positif terhadap pemberdayaan karyawan persepsian.

H4 : Komitmen berpengaruh positif terhadap tanggung jawab sosial perusahaanpersepsian dengan pemberdayaan karyawan persepsian sebagai variabel mediasi. 


\section{MODEL PENELITIAN}

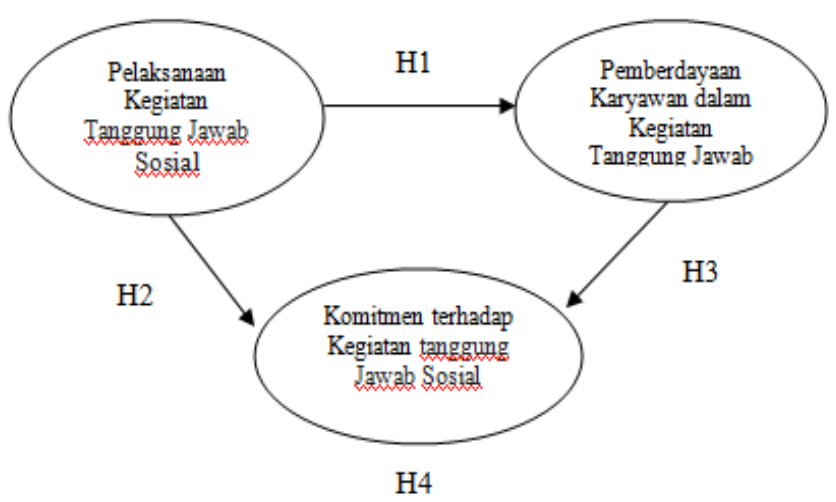

Gambar. 1. Model Penelitian

Model menjelaskan bahwa pendekatan penelitian kuantitatif, yang pelaksanaan kegiatan tanggung jawab sosial perusahaan persepsian berpengaruh secara langsung pada pemberdayaan karyawan dalam kegiatan tanggung jawab sosial perusahaan dan secara tidak langsung pada pemberdayaan karyawan dalam kegiatan tanggung jawab sosial perusahaan melalui mediasi komitmen.

\section{METODOLOGI PENELITIAN}

Penelitian pada dasarnya adalah sutu kegiatan atau proses sistematis untuk memecahkan masalah yang dilakukan dengan menerapkan metode ilmiah. Tujuan dari semua usaha ilmiah adalah untuk menjelaskan, memprediksikan, dan mengontrol fenomena

Kerlinger (1990) mendefinisikan penelitian ilmiah adalah penyelidikan yang sistematis, terkontrol, empiris, dan kritis, tentang fenomena sosial yang dibimbing oleh teori hipotesis tentang dugaan yang berhubungan dengan fenomena tersebut.Penelitian ini menggunakan menguji hubungan penelitian ilmiah yang sistematis terhadap bagian-bagian dan fenomena serta hubunganhubungannya.Desain penelitian ini menggunakan metode survey dengan alat pengumpul datanya adalah kuisioner.

\section{Definisi dan pengukuran Variabel}

\section{Pemberdayaan Karyawan Persepsian}

Menurut Wadhwa et al., (2015) pemberdayaan karyawan dapat didefinisikan sebagai prosedur dimana manajer berbagi kekuasaan, wewenang dan tanggung jawab dengan bawahan mereka untuk menyelesaikan tugas-tugas tertentu. Pemberdayaan karyawan persepsian diukur skala likert berdasarkan indikator: (1). Pekerjaan sangat sesuai dengan keinginan individu, (2). Kemauan menerima tanggung jawab, (3). Kesiapan menerima tugas-tugas yang lebih banyak, (4). Rasa untuk mencapai tujuan dalam organisasi, (5). Kemauan karyawan untuk diberdayakan. 


\section{Komitmen}

Robbins (2006) berpendapat bahwa komitmen organisasi adalah sejauh mana seseorang karyawan memihak pada suatu organisasi tertentu dan tujuan-tujuannya, dan berniat memelihara keanggotaan dalam organisasi itu. Komitmen diukur dengan skala liket berdasarkan indikator : (1). Meningkatnya keterlibatan dalam organisasi, (2). Keinginan untuk tetap tinggal dalam organisasi, (3). Rasa memiliki perusahaan, (4). Rasa tanggung jawab terhadap perusahaan

\section{Tanggung Jawab Sosial Persepsian}

Tanggung jawab sosial persepsian dapat didefinisikan sebagai kebijakan dan praktik yang berhubungan dengan nilai-nilai menemukan ketentuan hukum, persepsian kepada masyarakat dan lingkungan, serta komitmen perusahaan untuk berkontribusi pada perkembangan secara berkelanjutan. Tanggung jawab sosial persepsian diukur dengan skala liket berdasarkan indikator :
(1). Tanggung jawab terhadap masyarakat, (2). Rasa kepedulian terhadap nilai sosial, (3). Perhatian terhadap hak asasi manusia.

\section{Uji Validitas dan Reliabilitas}

1. Uji Validitas

Uji validitas dilakukan untuk mengukur seberapa baik konstruk penelitian didefinisikan oleh variabel teramati (Hair, 2006). Uji validitas adalah suatu pengujian untuk menganalisis faktor variabel-variabel yang terdapat dalam penelitian. Uji validitas digunakan untuk mengukur sah, atau valid tidaknya suatu kuesioner (Ghozali, 2009). Suatu kuisioner dikatakan valid jika pertanyaan pada kuisioner mampu untuk mengungkapkan sesuatu yang akan diukur oleh kuisioner tersebut. Uji validitas digunakan untuk mengukur sah atau valid tidaknya suatu kuesioner. Uji validitas menggunakanPearson Product Moment Correlation. Suatu variabel dikatakan valid jika nilai < 0,05 (Sugiono, 2014).

\begin{tabular}{ccc}
\hline $\begin{array}{c}\text { Butir } \\
\text { Kuesioner }\end{array}$ & Loading Factor & Keterangan \\
\hline PK 1 & 0,889 & Valid \\
PK 2 & 0,897 & Valid \\
KM 1 & 0,813 & Valid \\
KM 2 & 0,865 & Valid \\
CSR 1 & 0,793 & Valid \\
CSR 2 & 0,838 & Valid \\
CSR 3 & 0,783 & Valid \\
\hline
\end{tabular}

Tabel 1. Hasil Uji Validitas Kuesioner

Keterangan :

PK : Pemberdayaan Karyawan

KM : Komitmen

CSR :Corporate Social Responsibility (tanggung jawab sosial perusahaan)
Butir-butir kuisioner untuk mengukur variabel komitmen yaitu KM 1 dan KM 2 mempunyai nilai factor loading lebih besar dari 0,65 dan terekstrak dalam kolom yang sama. Maka KM 1 dan KM 2 berkorelasi tinggi satu sama lain dan valid untuk 
mengukur komitmen. Sedangkan, butir-butir kuisioner untuk mengukur variabel CSR, dua butir kuisioner mempunyai nilai loading factor lebih besar dari 0,65 dan terekstrak dalam satu kolom yang sama yaitu CSR 1, CSR 2 dan CSR 3. Hal ini mengidentifikasikan bahwa indikator yang mendasari kuisioner CSR 1, CSR 2 dan CSR 3 berkolerasi tinggi satu sama yang laindan valid untuk mengukur CSR.

\section{Uji Reliabilitas}

Uji reliabilitas adalah alat untuk mengukur suatu kuisioner yang merupakan indikator dari perubah atau konstruk. Suatu kuisioner dikatakan reliabel atau handal jika jawaban seseorang terhadap pernyataan adalah konsisten atau stabil dari waktu ke waktu.Uji reliabilitas dimaksudkan untuk mengukur suatu kuesioner yang merupakan indikator dari variabel. Reabilitas diukur dengan uji statistik. Suatu variabel dikatakan reliabel jika memberikan nilai Cronbach's Alpha > 0,6 (Sugiono, 2014).

\begin{tabular}{lcc}
\hline \multicolumn{1}{c}{ Variabel } & $\begin{array}{c}\text { Koefisien } \\
\text { Alpha }\end{array}$ & Keterangan \\
\hline Pemberdayaan Karyawan & 0,801 & Reliabel \\
Komitmen & 0,684 & Reliabel \\
Tanggung Jawab Sosial & 0,739 & Reliabel \\
\hline
\end{tabular}

Tabel 2. Hasil Uji reliabilitas

Berdasarkan tabel diatas menunjukkan bahwa semua item kuesioner dalam variabel yang diteliti mempunyai nilai reliabilitas lebih besar dari 0,6 dan dapat disimpulkan semua item kuesioner reliabel digunakan dalam mengambil data.

\section{Teknik Penyampelan}

Peneliti menggunakan probability cluster sampling (area sampling) juga cluster random sampling. Teknik ini digunakan bilamana populasi tidak terdiri dari individuindividu, melainkan terdiri dari kelompokkelompok individu atau cluster. Teknik sampling daerah digunakan untuk menentukan sampel bila objek yang akan diteliti atau sumber data sangat luas, Margono (2004).

\section{E. METODE PENGUMPULAN DATA}

Adapun teknik atau cara pengumpulan data yang dilakukan penulis adalah dengan menggunakan kuesioner daftar pertanyaan tertulis yang ditujukan kepada responden. Peneliti akan mengukur secara langsung data yang diperoleh melalui riset lapangan dengan menyebarkan kuisioner tentang komitmen organisasi terhadap tanggung jawab sosial persepsian yang pada akhirnya ke pemberdayaan karyawan persepsian. Kuisioner akan diukur dengan skala likert menurut Djaali (2008:28) ialah skala yang dapat dipergunakan untuk mengukur sikap, pendapat, dan persepsi seseorang atau sekelompok orang tentang suatu gejala atau fenomena pendidikan. Skala pada bentuk 
pertanyaan ini, responden diminta menjawab pertanyaan dalam bentuk skala untuk mengukur sikap responden terhadap pertanyaan-pertanyaan dalam kuisioner. Likert 1-5 digunakan pada penelitian ini yang terbagi menjadi:

1. Sangat Setuju (SS)diberi skor 5

2. Setuju (S)diberi skor 4

3. Cukup Setuju (CS)diberi skor 3

4. Tidak Setuju (TS)diberi skor 2

5. Sangat Tidak Setuju (STS)diberi skor 1

\section{F. HASIL DAN PEMBAHASAN}

\section{Deskripsi Sampel}

Berdasarkan hasil uji analisis dan pembahasan, maka bab ini akan membahas tentang deskripsi sampel. Responden yang dipilih adalah karyawan medis dan non medis. Sampel yang dapat diambil ada 100 responden yang mempunyai komitmen tinggi di RSJD Dr. Arif Zainudin Surakarta.

\section{Hasil Analisis Regresi}

1. Analisis regresi peran komitmen pada hubungan antara tanggung jawab sosial perusahaan persepsian dan pemberdayaan karyawan.

Hubungan antara konstruk yang diteliti diuji dengan analisis regresi bertingkat. Hasil analisis regresi dapat dijelaskan sebagai berikut:

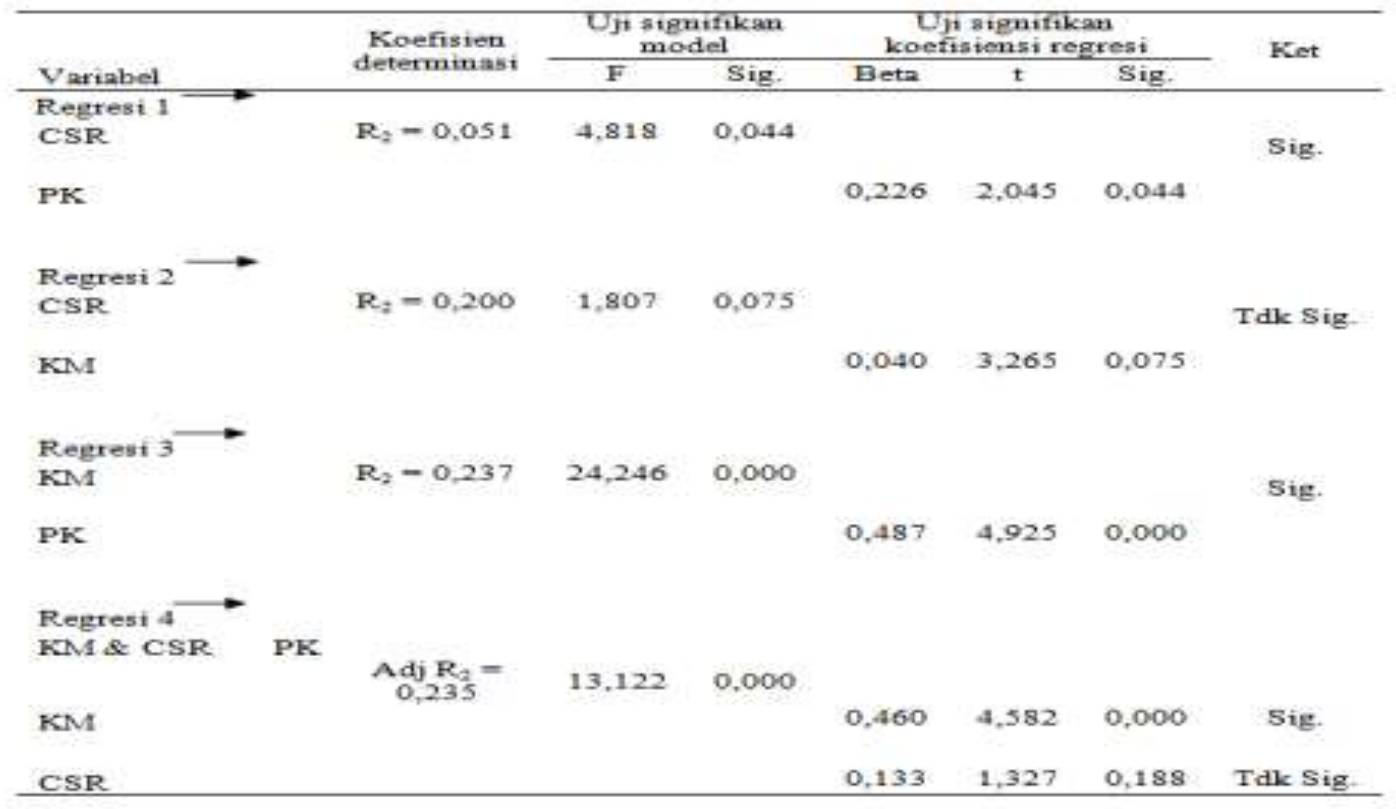

Sumber: Data yang diolah, 2019.

Tabel 3. Hasil Analisis Regresi 
Keterangan:

1. PK : Pemberdayaan Karyawan

2. $\mathrm{KM}$ : Komitmen

3. CSR :Corporate

Responsibility

Social

jawab sosial perusahaan)

Pada regresi ke 1 terlihat hubungan antar CSR terhadap pemberdayaan karyawan dinyatakan signifikan. Pada regresi ke 2 terlihat hubungan antara CSR terhadap komitmen dinyatakan tidak signifikan dan regresi ke 3 terlihat hubungan komitmen dan pemberdayaan karyawan dinyatakan signifikan. Maka hipotesis pada $\mathrm{H}_{1}$ dan $\mathrm{H}_{3}$ terdukung. Sedangkan, $\mathrm{H}_{2}$ tidak terdukung. Dari pengolahan data diatas dapat di simpulkan bahwa $\mathrm{H}_{4}$ tidak terdukung. Sehingga Komitmen tidak signifikan memediasi hubungan antara CSR terhadap Pemberdayaan Karyawan.

\section{Pembahasan}

\section{Pengaruh Variabel Tanggung Jawab Sosial Perusahaan Terhadap Pemberdayaan Karyawan}

Berdasarkan hasil uji hipotesis dapat disimpulkan bahwa, hasil penelitian ini sesuai dengan penelitian terdahulu yang dikemukakan oleh Burke (1986) strategi pengaturan tujuan kinerja untuk karyawan dengan tugas yang menantang dan memberi inspirasi sebagai bentukmemberdayakan karyawan untuk berpartisipasi dalam pengambilan keputusan yang berkaitan dengan tanggung jawab sosial perusahaan dan memberikan perhatian kepada karyawan sebagai strategi pemberdayaan terdapat pengaruh yang signifikan antara Tanggung Jawab Sosial Perusahaan terhadap Pemberdayaan Karyawan. Memberi indikasi bahwa Tanggung Jawab Sosial Perusahaan cukup kuat pengaruhnya terhadap pemberdayaan karyawan. Pengujian tersebut dibuktikan dengan perolehan nilai $t$ sebesar 2,045 dan nilai signifikansi sebesar $0,044 \leq 0,05$ sehingga hipotesis pertama dalam penelitian ini diterima. Hasil penelitian ini dapat disimpulkan Tanggung Jawab Sosial Perusahaan berpengaruh positif terhadap pemberdayaan karyawan dengan demikian dapat dikatakan bahwa orang yang memiliki nilai sosial yang tinggi akan menilai Tanggung Jawab Sosial Perusahaan merupakan perilaku sosial, sesuai dengan nilai-nilai yang karyawan percayai. Individu yang cocok dengan organisasi yang melakukan Tanggung Jawab Sosial Perusahaan maka persepsi individu tersebut terhadap organisasi akan menilai bahwa perusahaan tersebut memiliki nilai sosial yang tinggi dan karyawan akan siap untuk diberdayakan oleh organisasi.

\section{Pengaruh Variabel Tanggung Jawab Sosial Perusahaan Terhadap Komitmen}

Berdasarkan hasil uji hipotesis dapat disimpulkan bahwa tidak ada pengaruh yang signifikan antara variabel Tanggung Jawab Sosial Perusahaan dan Komitmen. Hal ini 
memberi indikasi bahwa Tanggung Jawab Sosial Perusahaan tidak kuat pengaruhnya terhadap Komitmen. Pengujian menunjukkan nilai t hitung sebesar 1,807 dengan nilai signifikasi sebesar 0,075. Dikarenakan nilai signifikasi $0,075 \geq 0,05$, maka dapat disimpulkan tidak ada pengaruh yang signifikan antara variabel independen (Tanggung Jawab Sosial Perusahaan) terhadap variabel dependen (Komitmen). Karena keterbatasan dalam penelitian ini hanya menyebar kuisioner di salah satu rumah sakit saja sehingga mengakibatkan suatu variabel tidak signifikan.

Hasil penelitian ini tidak didukung penelitian yang dilakukan olehStawiski, (2010) untuk menghasilkan manfaat maksimal dari tanggung jawab sosial perusahaan, karyawan harus dilibatkan dalam pengambilan keputusan mengenai tindakan mana yang harus dilakukan terkait dengan lingkungan, komunitas, dan juga karyawan itu sendiri.Peterson (2004) kinerja sosial perusahaan dapat berkontribusi positif terhadap komitmen, baik karena karyawan cenderung mengidentifikasi dengan organisasi yang memiliki nilai positif dalam kegiatan tanggung jawab sosial dan karena karyawan mendapat manfaat dari hubungan kegiatan tanggung jawab sosial oleh organisasi.

\section{Pengaruh Variabel Tanggung Jawab Sosial Perusahaan Terhadap Pemberdayaan Karyawan dan Komitmen}

Berdasarkan hasil uji hipotesis dapat disimpulkan bahwa hasil penelitian ini sesuai dengan penelitian terdahulu yang dilakukan oleh Dawkins (2004) kontribusi tanggung jawab sosial perusahaan menarik potensi yang dimotivasi karyawan dan meningkatkan tingkat komitmen yang ada para karyawan. Pengujian persamaan menunjukkan nilai $t$ hitung sebesar 4,582 dengan nilai signifikasi sebesar 0,000 . Dikarenakan nilai signifikasi $0,000 \leq 0,05$, dari hasil tersebut ada pengaruh yang signifikan antara variabel independen (Tanggung Jawab Sosial Perusahaan, Komitmen) terhadap variabel dependen (Pemberdayaan Karyawan).

\section{G. PENUTUP}

\section{Kesimpulan}

Penelitian ini bertujuan menguji pengaruh peran komitmen pada hubungan antara Tanggung Jawab Sosial Perusahaan persepsian dengan pemberdayaan karyawan. Berdasarkan hasil pengolahan data menjelaskan bahwa semua hipotesis dalam studi ini terdukung. Berdasarkan hasil analisis yang telah dilakukan maka dapat ditarik kesimpulan sebagai berikut: (1). Tanggung Jawab Sosial Perusahaan berpengaruh pada Pemberdayaan Karyawan, (2). Tanggung Jawab Sosial Perusahaan berpengruh pada Komitmen, (3). Komitmen tidak memediasi hubungan antara Tanggung Jawab Sosial Perusahaan dan Pemberdayaan Karyawan pelaksanaan kegiatan tanggung jawab sosial di Rumah Sakit Dr. Arif Zainudin bisa berjalan dengan 
baik tanpa adanya komitmen karyawan sebagai variabel mediasi antara tanggung jawab sosial perusahaan dengan pemberdayaan karyawan.

\section{Saran}

Berdasarkan hasil kesimpulan dan pembahasan maka dapat diajukan beberapa saran sebagai beikut :

1. Sebaiknya pihak rumah sakit menginformasikan ulang kepada seluruh karyawan bahwa rumah sakit tersebut menerima sebagai tempat penelitian agar karyawan bersedia untuk mengisi kuesioner.

2. Untuk penelitian selanjutnya mengharapkan dapat memperluas obyek penelitian dengan menghadirkan variabel indikator yang berbeda.

\section{REFERENSI}

Aan Komariah, Djam'an Satori, (2011). Metode Penelitian Kualitatif. Bandung, Alfabeta.

Abdullah, Rohi, (2015). Web programing is easy. Jakarta: Elek Media Komputindo Ali I, Kashif U.R, Syed I.A, Jamil Y, dan Maria Z, (2010). Corporate social responsibility influences, employee commitment and organizational performance. African Journal of Business Management Vol. 4(12), pp. 2796-2801.

Amirudin R., (2009). Buku ajar ilmu penyakit dalam: fisiologi dan biokimia hati. Edisi
V. Jakarta. Interna publishing. Hal: 627.

Appelbaum, S.H. \& Hare, A. (1996). Selfefficacy as $A$ Mediator of goal setting and performance. Some human resource applications. Journal of managerial psychology, 11 (3), 3347.

Arifin, Zainal, (2014). Penelitian Pendidikan: Metode dan Paradigma Baru. Bandung: PT. Remaja Rosdakarya.

Babbie, Earl, (2001). The Practice of Social Research. California: Wardsworth publishing company.

Beny, (2012). Psikologi pendidikan dan pengajaran. Jakarta: PT. Buku Seru.

Bowen, Lawyer, (1992). The Empowerment of Service Recovery: Developing a New Construct. International journal of service industry management 10 (2): 118-131.

Cecilia, (2008). Pengaruh kepuasan kerja terhadap kinerja individual dengan self esteem dan self efficacy sebagai variabel intervening. Jurnal bisnis dan akuntansi Vol. 10, No.1, April.

Dewettinck, K, (2011). Linking leadership empowerment behavior to employee attitudes and behavioural interntions, testing the mediating role of psychological empowerment. Personnel review 40 (3): 284-305.

Dessler, Gary, (2015). Manajemen Sumber Daya Manusia. Jakarta: salemba empat. 
Dizgah IM, Mirjalili N, (2011). Unstimulated whole saliva 25 hydroxycholecalciferol in patients with xerostomia in menopausal women. Aging Clin Exp Res 147-151.

Djaali, (2008). Psikologi pendidikan. Jakarta: Bumi Aksara.

Eddle R, (2017). Tanggung jawab bisnis terhadap Ham. 2 juni 2017.

Freeman, C. (2002). Communities of practice: bridging technology and knowledge assessment. Journal of knowledge management. Vol. 4, no. 1.

Fu W, Satish P, Deshpande, (2014). The Impact of Caring Climate, Job Satisfaction, and Organizational Commitment on Job Performance of Employees in a China's Insurance Company. J Bus Ethics (2014) 124:339-349 doi 10.1007/s10551013-1876-y

Fulford, M D., Enz, C. A. (1995). The impact of empowerment on service empowerment. Journal of managerial issues, Vol, 7 No. 2,pp. 161-175.

Ghozali, Imam, (2009). "Aplikasi analisis multivariate dengan program SPSS". Semarang: UNDIP

Greenberg, Robert Baron, (2003). Behavior in organizations (understanding and managing the human side of work). Eight edition, Prentice Hall.

Hair, J.F, (2006). Multivariate Data Analysis. Edisi 5. Jakarta: Gramedia Pustaka Utama.
Hanaysha, (2016). Testing the effects of food quality, price fairness, and physical environment on customer satisfaction in fast food restaurant industry, journal of asian economic and social society vol.6, issue 2, 2016, pp. 31-40.

Hanif, (2001). Analisis dan perancangan sistem informasi. Yogyakarta: ANDI

Hawkins, Best, Coney, (2004). Consumer Behavior, Building Marketing Strategy International Edition. Mc Graw Hill Companies, inc.

Hsieh S.O, Herng C.C, Ya-Hui H, Pei-Shen $\mathrm{H}$, Li-Chin C, Wei-Chou C, (2016) The Perceptions and Expectations Toward the Social Responsibility of Hospitals and Organizational Commitment of Nursing Staff.The Journal of Nursing ResearchVol. 24, No. 3

Iftikhar A, Sheikh R.M, (2017) Effect of Team work, Employee Empowerment and Training on Employee Performance.International Journal of Academic Research in Business and Social Sciences 2017, Vol. 7, No. 11 Isaiah O, Ugboro, Kofi Obeng, (2000) Top management leadership, employee empowerment, job satisfaction, and customer satisfaaction in TQM organizations: an empirical study. Juornal of Quality Management 5(2000) 247272

Ismiyanto, PC. S., M. Pd (2003). Metode penelitian. Semarang: FBS UNNES. Jamaluddin. 
Janssen.O, (2004). The barrier effect of conflict with superiors in the relationship between employee empowerment and organizational commitment.Work \& stress, january_march 2004, vol. 18, no. 1, 56_65

Januarti, Apriyanti, (2006). Pengaruh tanggung jawab sosial perusahaan terhadap kinerja keuangan. Jurnal MAKSI. Vol 5 No. 2 Agustus: 227-243.

Kelinger, F.N. (1990). Asas-asas penelitian behavioral. Yogyakarta: Gadjah Mada University Press.

Kotler, Philip, (2005). Manajemen Pemasaran. Jilid 1 dan 2. Jakarta: PT. Indeks Kelompok Gramedia.

Kreitner, Kincki, (2012). Organizational Behavior. New York: McGraw-Hill.

Malik W U, Muqaddas J, Syed T H, (2017) Influence of Transformational Leadership Components on Job Satisfaction and Organizational Commitment. Pakistan Journal of Commerce and Social Sciences 2017, Vol. 11 (1), 146-165

Margono. (2004). Metodologi Penelitian Pendidikan. Jakarta: PT. Rineka Cipta. Mulyadi, (2000). Akuntansi biaya, Edisi kelima. Yogyakarta: penerbit lembaga universitas gadjah mada.

Muhammad, (2014). Metodologi dan aplikasi riset pendidikan. Jakarta: PT. Bumi Aksara.
Mutiara, (2004). Manajemen sumber daya manusia. Bogor: ghalia indonesia.

Reksodipuro, (2006). Buku ajar ilmu penyakit dalam, edisi 4. Jakarta: pusat penerbitan departemen ilmu penyakit dalam fakultas kedokteran universitas indonesia. Hal: 481-482.

Ridwan, (2010). Dasar-dasar Statistika. Bandung: Alfabeta.

Rim H, Sung-Un Y, Jaejin L, (2016) Strategic partnerships with nonprofits in corporate social responsibility (CSR): The mediating role of perceived altruism and organizational identification. Journal of Business Research 69 (2016) 3213-3219.

Robbins, Stephen, (2006). Perilaku Organisasi. Pretice hall, edisi kesepuluh sabardini 2006, "peningkatan kinerja melalui perilaku kerja berdasarkan kecerdasan emosional". Telaah bisnis, Vol.7, No.1.

Saxena M dan Dharmesh K. M, (2017) CSR perception: a global opportunity in management education. Industrial and Commercial Training, Vol. 49 Issue: 5, pp.231-244.

Sen S, (2006) The Role of Corporate Social Responsibility in Strengthening Multiple Stakeholder Relationships $A$ Field Experiment. Journal of the Academy of Marketing Science. Volume 34, No. 2, pages 158-166.

Shin I, Won-Moo H, Seongho K, (2016). Employees' Perceptions of Corporate Social Responsibility and Job 
Performance: A Sequential Mediation Model. Sustainability 2016, 8, 493; doi:10.3390/su8050493.

Umar H, (2014). Majalah hukum forum akademika. No. 1 vol 25, maret 2014.

Velthouse, B.A., (1990). Cognitive elements of empowerment: an interpretive model of intrinsic task motivation. Academy of management review, 15(4), pp.666-681.

Wadhwa, J., Nair, A., (2015). Self-emulsifying therapeutic system: a potential apporoach for delivery of lipophilic drugs. Brazilian Journal of Pharmaceutical Sciences. 